\title{
International trade risks
}

\author{
Eva Hoke ${ }^{1, *}$, Jan Marada ${ }^{1}$, and Romana Heinzová ${ }^{1}$ \\ ${ }^{1}$ Tomas Bata University in Zlín, Faculty of Logistics and Crisis Management, Studentské nám. 1532, 68601 Uherské Hradiště, Czech \\ Republic
}

\begin{abstract}
There are a number of risks in the international trade associated with differences in the regulatory environment, logistics, geographical distance and the common misunderstanding among business partners. It would not be possible to comprehensively cover all risks because of the scale of the contribution. The paper deals the characteristics and mapping of international trade risks in the area of protection of intellectual property rights and consumer protection, as well as the processing of statistics on the occurrence of counterfeit frequency in the Czech Republic. The authors briefly described the basic concepts such as counterfeit, dangerous product, dangerous food, intellectual property rights, and international trade risks. The main part of the contribution already contains the interpretation of the achieved results. Based on the analysis and controlled interviews with practitioners, the customs procedure is described and the statistics of goods detained in the customs market both on the national market and on the EU market are processed and compared. The conclusion of the work summarizes the results and outlines possible future development of the Customs Administration of the Czech Republic.
\end{abstract}

\section{Introduction}

The presented paper deals with the characteristics and mapping of international trade risks in the area of protection of intellectual property and consumer protection. In the beginning, it is necessary to introduce the basic concepts that will be in the work and will accompany the whole work. These are counterfeits, dangerous foods, intellectual property rights, or international trade risks.

We can define counterfeit according to Act No. 191/1999 Coll., about measures concerning the import, export, and re-export of goods infringing certain intellectual property rights. A counterfeit is a commodity, including its packaging, in which, without the consent of the owner of the trademark, the mark is identical or interchangeable with the mark registered for goods which thereby infringes the rights of the trademark proprietor. Fake goods are also all things bearing the same or similar designation (marks, logos, labels, stickers, brochures, instructions for use, documents on warranty, etc.) [1]

According to Regulation (EC) $178 / 2002$ on the general principles and requirements of food law, a dangerous foodstuff is a food that we consider a food harmful to health and a food unsuitable for human consumption. [2]

Intellectual property refers (IPR) to the rights to intangible goods created by human intellectual activity. We divide these rights into copyright law, which is the right to copyright and artistic works, and to the right to industrial property, which relates to the results of intellectual activity in the economic field (inventions, designs, trademarks). The intellectual property owner (author) may grant to another person rights to dispose of intellectual property through a license. [3]

IPR protection can also be interpreted as a 'location advantage', as it is territorial in nature and hence differs across countries. [4] This explains why in recent years many developing and emerging economies have reformed their IPR legislation to reduce the FDI attractiveness gap vis-à-vis countries already providing strong IPRs, to avoid the risk of being left behind in the global competition for capital and technology $[5,6]$

Brand names or trademarks carry incredible economic power and prestige. There is increasing recognition by world bodies that intellectual property (IP), whether manifested in patents, trademarks, copyrights or trade secrets, is highly valuable and must be protected through robust IP enforcement. The increased recognition of the value of IP has led to stronger enforcement of IP protection, an increase in IP litigation, and growing policy actions that are focused on how that protection should be manifested. [7]

The primary forms of IP are patents, trademark, copyrights and trade secrets. A patent is an intellectual (or industrial) property that confers to its owner or holder monopoly rights to a product or process over a stipulated period of time. Applications are granted on the basis of innovation and non-obviousness [8]

Notorious dens of IP piracy such as China, India and Brazil have begun to realize that, as their own economies

Corresponding author: hoke@utb.cz 
mature, the intellectual capital being created domestically within each country is valuable and must be protected. A natural consequence is the concurrent enforcement and protection of their own IP if mutual respect and protection of IP is to exist. The World Health Organization (WHO) estimates that at least $6 \%$ of the pharmaceuticals sold worldwide every year are counterfeit, and are valued at more than $\$ 30$ billion. The OECD estimates that the total costs of counterfeiting are equivalent to between $5 \%$ and $7 \%$ of world trade. [7]

As these statistics make clear, focusing on piracy issues and protection of IP is becoming a central focus of diplomacy and trade talks internationally, with most nations having a significant stake in how this problem is resolved. The USA is an interesting natural laboratory as patent, trademark and copyright litigation battles have been raging domestically for some time. This paper describes some of the trends and IP litigation activities that are transpiring in the USA, where IP enforcement is taken very seriously. [7]

\subsection{Customs administration of the Czech Republic}

The Czech customs administration, as well as the customs administration of other states, has two basic tasks: the protection and regulation of the domestic market through the collection of customs duties on imported goods and the supervision of such goods not endangering human or animal life or health. The evolution of the economic situation, including the start of preparations for EU membership, urgently required the customs administration to facilitate legal international trade as much as possible. This objective could only be achieved through the modernization of the customs administration, both in customs and technical equipment, in particular, the Customs Information System. Another significant fact that predetermined the current form of the Czech Customs Administration was the accession of the Czech Republic to the European Union. From the point of view of customs administration, it was not only the act of entry itself but a long-term period of approximation of customs legislation and customs procedures with European standards. [9]

The Customs Administration of the Czech Republic is actively involved in the fight against counterfeiting and piracy, using its powers based on national and European legislation. The customs authorities are entitled to intervene against goods suspected of infringing intellectual property rights and to allow the holders of the rights in question to protect them. [9]

\subsection{Risks of international trade}

There are a lot of risks of doing business in foreign markets, for example, from the development of currency rates, from the economic or political situation in different territories, etc. Each business area is associated with risks that can cause the result to be different from the expected result. random influences. The risk of international economic relations has, to some extent, increased over the past decades in the context of economic development, variability in value categories, political transformations and the interconnection of markets in a context of globalization. It manifests itself in changes in exchange rates, changes in price relations, interest rates, the inability of some states to meet their foreign payment obligations, in political risks, etc. The risks of international economic relations represent a relatively diverse group. Risk sharing and nomenclature in this area are not stable. In general, different criteria are used for risk sharing, such as measurability, impact on the outcome, causes of formation, decision-making, etc.

There are close links and links between the different types of risk. Some types of risks complement each other and occur together, therefore the risks need to be assessed comprehensively and respect their context. Business policy measures aimed at reducing one risk may aggravate other risks. [10]

Risk sharing [10]:

- market risks;

- commercial risks;

- transport risks;

- territorial risks;

- exchange rate risks;

- responsibility risks and other types of risks.

In the work we will focus mainly on the last type of risks, which are the responsibility risks. This risk is related to broad consumer protection in the markets of some developed countries, especially the US and the EU. In these countries, the manufacturer is always liable for damage to health or property that may result from defects in the product. Product safety is therefore a basic requirement when exporting some products to developed countries. Insurance is the most effective and necessary tool to protect against this risk when exporting to these markets. In this context, it should be noted that even in the Czech Republic the producer's liability is regulated in accordance with the EEC Directive of 1985, namely the Act on Liability for Damage Caused by Product Defect No. 59/1998 Coll.). [10]

\section{Methodology}

The main aim of this paper is to map and characterize the risks of international trade both on the national market and on the EU market. The second aim is to clarify the functioning and competences of the Customs Administration of the Czech Republic in the field of protection of intellectual property rights, what is responsible subject for this area.

The following methods were used to achieve the above tasks. The input method is a literature search that defines the theoretical basis of the issue. Further, it was used controlled interviews with practitioners, especially with the Head of the Intellectual Property Protection Department in Hradec Králové, the Customs Administration of the Czech Republic, were used as a data collection technique. An analysis method and descriptive statistics were used to interpret and describe the data, which processes data in the form of graphs and 
tables and calculates their numerical characteristics. In conclusion, the results of the research are summarized by the method of synthesis and serve as a platform for possible future developments in the studied areas.

\section{Results}

After the Czech Republic's accession to the European Union, the Customs Administration of the Czech Republic has undergone a number of changes. Following a wave of layoffs and an imaginary earthquake in Customs, the implementation of the new EU customs regulations has begun. Today, Customs Administration is a modern security force based not only on information technology, but also the most competent choir. Consumer protection and intellectual property rights protection are among the important competences available to the Customs.

Information on this contribution was provided directly by the Customs Administration. We also received information from consumers buying products from third countries.

To understand the issue, we need to divide the protection of intellectual property rights into two areas examined where IPR infringements occur. These are goods detained in customs and goods detained on the national market. It is therefore necessary to monitor these risks associated with international trade and to look out for those third countries that are known to export counterfeits. Goods detained in customs are goods that come to us from third countries. These are, for example, Aliexpress pages. In connection with the protection of intellectual property rights, it is necessary to mention the international event in which the Customs Administration of the Czech Republic participated in the name IN OUR SITES IX. This event lasted 9 months and resulted in the closure of 33,600 websites that offered counterfeits via the Internet.

The statistics of goods detained in customs clearance in January 2019 are presented in the following table and graph.

Table 1. The statistics of goods detained in customs clearance.

\begin{tabular}{|c|c|c|}
\hline Clothes & $\begin{array}{c}\text { The } \\
\text { quantity }\end{array}$ & $\begin{array}{c}\text { Value in } \\
\text { CZK }\end{array}$ \\
\hline Sport shoes & 20 & 48000 \\
\hline Other footwear & 1 & 3000 \\
\hline $\begin{array}{c}\text { Bags incl. } \\
\text { wallets and } \\
\text { purses }\end{array}$ & 17 & 410300 \\
\hline $\begin{array}{c}\text { Watches } \\
\text { Jewelery and } \\
\text { other } \\
\text { accessories }\end{array}$ & 3 & 3000 \\
\hline
\end{tabular}

\begin{tabular}{|c|c|c|}
\hline Mobile phones & 49 & 375000 \\
\hline $\begin{array}{c}\text { Parts and } \\
\text { technical } \\
\text { accessories for } \\
\text { mobile phones }\end{array}$ & 520 & 1547100 \\
\hline $\begin{array}{c}\text { Audio/Video } \\
\text { Devices }\end{array}$ & 526 & 350500 \\
\hline $\begin{array}{c}\text { Memory cards, } \\
\text { external } \\
\text { memory }\end{array}$ & 53 & 7950 \\
\hline $\begin{array}{c}\text { Computer } \\
\text { Hardware incl. } \\
\text { technical } \\
\text { accessories and } \\
\text { components }\end{array}$ & 72000 & 3971 \\
\hline Toys & 51 & 27400 \\
\hline $\begin{array}{c}\text { All drugs incl. } \\
\text { steroids and } \\
\text { contraception }\end{array}$ & 832 & 334704 \\
\hline Vehicles & 1 & 1500 \\
\hline $\begin{array}{c}\text { Labels, tags, } \\
\text { stickers }\end{array}$ & 60 & 30000 \\
\hline Other & 1021 & 183022 \\
\hline Total & 75186 & 3919947 \\
\hline
\end{tabular}

Table 1. and Fig.1 show, that intellectual property rights are currently the most violated (by a number of pieces) in the category of computer hardware and computer peripherals (mice, keyboards, etc.).

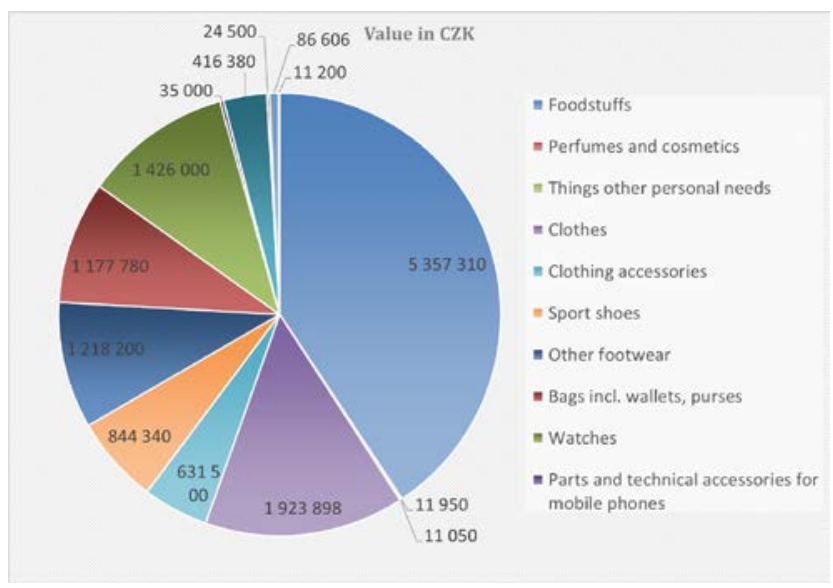

Fig. 1. Value in CZK of goods detained in customs clearance.

Interestingly, the total value of these counterfeits is very low. On the other hand, technical accessories and components for mobile phones dominate the value of counterfeit goods. In our contribution, we focused on a very important item of counterfeit medicines, steroids, and contraception.

In case, these items fall into the hands of the end customer, they can cause very serious health problems. Also significant is their total value in relation to pieces 
of detained goods. The possibility of eliminating the risk of international trade in pharmaceuticals and their counterfeits is public awareness. The above statistics show that there are still consumers in society who are being tempted to low price these medicines. These consumers do not think where the product comes from and often do not even realize that they order the items from unverified websites and from unknown companies and sellers.

Up to this point, we have focused on goods that are subject to customs supervision. The Customs Administration of the Czech Republic has the right to intervene against goods not subject to customs supervision. There is not much in a country where customs authorities have the right to intervene on goods not subject to customs supervision. The Czech Republic is one of them. This power can be picked up and identified as important and positive in terms of risk management. We have an armed corps here that can check suspicious goods in the event of errors by other authorities. The customs administration also has the only overall overview of all the goods that go to us across the border and can thus cooperate with other institutions in this way and effectively solve the given issue.

In the following Table 2. we can see the current state of seized goods on the national market, again in January 2019.

Table 2. The statistics of goods detained on the national market.

\begin{tabular}{|c|c|c|}
\hline Foodstuffs & $\begin{array}{c}\text { The } \\
\text { quantity }\end{array}$ & $\begin{array}{c}\text { Value in } \\
\text { CZK }\end{array}$ \\
\hline $\begin{array}{c}\text { Perfumes and } \\
\text { cosmetics }\end{array}$ & 13935 & 5357310 \\
\hline $\begin{array}{c}\text { Things other } \\
\text { personal } \\
\text { needs }\end{array}$ & 91 & 11050 \\
\hline $\begin{array}{c}\text { Clothes } \\
\text { Clothing } \\
\text { accessories }\end{array}$ & 376 & 1923898 \\
\hline $\begin{array}{c}\text { Sport shoes } \\
\text { Other } \\
\text { footwear }\end{array}$ & 249 & 844340 \\
\hline $\begin{array}{c}\text { Bags incl. } \\
\text { wallets, } \\
\text { purses }\end{array}$ & 91 & 1177780 \\
\hline $\begin{array}{c}\text { Watches } \\
\text { phones }\end{array}$ & 8 & 1426000 \\
\hline $\begin{array}{c}\text { Parts and } \\
\text { technical } \\
\text { accessories } \\
\text { for mobile } \\
\text { Devices }\end{array}$ & 7 & 35000 \\
\hline audio/Video & 132 & 416380 \\
\hline
\end{tabular}

\begin{tabular}{|c|c|c|}
\hline $\begin{array}{c}\text { Memory } \\
\text { cards, } \\
\text { external } \\
\text { memory }\end{array}$ & 48 & 24500 \\
\hline Toys & 167 & 86606 \\
\hline Lighters & 17 & 11200 \\
\hline Total & 15901 & 13175714 \\
\hline
\end{tabular}

Statistics clearly show that food is the current trend in IPR infringements. They completely dominate both quantity and value. Thus, they are common foods (such as confectionery) on which trademarks or works of art related to audiovisual works (films, singers, music bands, etc.) are placed.

Rather, food only breaks intellectual property rights and is not so important to consumer protection. This is the basic activity that the customs administration has in relation to intellectual property rights, which is also the protection of their owners.

A more interesting section in terms of consumer protection in the national market is the section of toys and the perfume section. Toys are in this case again dangerous mainly because they are intended for children who do not know whether their health can endanger the toy. The counterfeit perfume section, in turn, is of interest to the consumer in that the consumer can observe various adverse effects. These cosmetics can be made from different, unhealthy substances for the body. These perfumes cause eczema, rash or allergic reactions. However, the perfume counterfeit can be recognized in such a way that its fragrance evaporates much faster than the original. In these sections, education as in previous cases would not be a very effective tool. The consumer cannot know if there is a fake or not on the shelf. We can only eliminate the risk by purchasing cosmetic products and toys only by verified and reliable sellers.

\section{Conclusion}

International trade offers not only a number of opportunities, but also a number of risks that do not exist on the domestic market. The issue of the risks of international trade is very wide, and because of the scope of the contribution, the contribution was focused on the protection of intellectual property rights and the area of counterfeits. We have analyzed the current situation in the field of combating counterfeits. The results of the processed statistics showed that the most significant representation among counterfeit products coming to the Czech market is food, toys and electronics. The most important body for combating counterfeits is the Customs Administration of the Czech Republic, which in the future should become a law enforcement agency and minimize the risk associated with this issue. Another effective tool for reducing the risks of counterfeiting is the modernization of information technology.

This research was supported by support research program of Tomas Bata University in Zlín (RVO). 


\section{References}

1. Competence of Authorities of the Customs Administration of the Czech Republic in Relation to Enforcement of Intellectual Property Rights Act No. 355/2014 Coll., Czech Republic, 2015 [Accessed: 2019-03-27].

2. IPR Infringements: Facts and figures. European commission [Internet], Available from: https://ec.europa.eu/taxation_customs/business/custo ms-controls/counterfeit-piracy-other-iprviolations/ipr-infringements-facts-figures_en (2018)

3. P. Sulc, A. Bartos. Copyright: in questions and answers (Pierot, Prague, 2012)

4. P.C.A. Braga, C. Fink. DJCIL, 9 (1998)

5. K. E. Maskus. Policy Discussion Paper No. 0022, Centre for International Economic Studies, (University of Adelaide, Australia 2000)

6. S. Adams, IBR, 3,3 (2010)

7. S. Hoti, M. McAleer, D. Slottje. JES, 20, 4 (2006)

8. S.M. Besen, L.J. Raskind, JEP, 5,1 (1991)

9. Customs Administration of the Czech Republic. [Internet], Available from: https://www.celnisprava.cz/cz/o-nas/Stranky/oceske-cs.aspx (2015)

10. H. Machkova, E. Cernohlavkova, A. Sato. International business operations (Grada, Prague, 2014) 